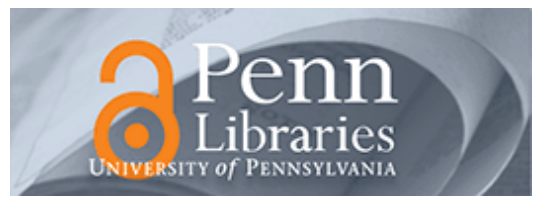

University of Pennsylvania ScholarlyCommons

$11-2013$

\title{
Social Democracy or Corporate Libertarianism? Conflicting Media Policy Narratives in the Wake of Market Failure
}

Victor Pickard

University of Pennsylvania, vpickard@asc.upenn.edu

Follow this and additional works at: https://repository.upenn.edu/asc_papers

Part of the Communication Commons

\section{Recommended Citation}

Pickard, V. (2013). Social Democracy or Corporate Libertarianism? Conflicting Media Policy Narratives in the Wake of Market Failure. Communication Theory, 23 (4), 336-355. https://doi.org/doi:10.1111/ comt.12021

This paper is posted at ScholarlyCommons. https://repository.upenn.edu/asc_papers/444

For more information, please contact repository@pobox.upenn.edu. 


\title{
Social Democracy or Corporate Libertarianism? Conflicting Media Policy Narratives in the Wake of Market Failure
}

\author{
Abstract \\ Assuming that crucial public services should not be left entirely to market-driven forces, American \\ policymakers attempted to establish safeguards for news media. An examination of conflicting narratives \\ within postwar policy debates suggests that the US evaded this path largely because of a concerted \\ backlash-often in the form of red-baiting-encouraged by threatened newspaper and broadcast \\ industries. Many lessons, parallels, and forgotten antecedents for current American media policy can be \\ drawn from the postwar 1940s. Thus, it is instructive to explore how these earlier debates were framed, \\ particularly in response to what might be referred to as "market failure." Given the worsening journalism \\ crisis and other persistent media policy challenges, this analysis of market failure holds much \\ contemporary relevance. \\ Disciplines \\ Communication | Social and Behavioral Sciences
}




\title{
Social Democracy or Corporate Libertarianism? Conflicting Media Policy Narratives in the Wake of Market Failure
}

\author{
Victor Pickard \\ The Annenberg School for Communication, University of Pennsylvania, Philadelphia, PA 19104, USA \\ Assuming that crucial public services should not be left entirely to market-driven forces, American policymakers \\ attempted to establish safeguards for news media. An examination of conflicting narratives within postwar policy \\ debates suggests that the US evaded this path largely because of a concerted backlash-often in the form of red- \\ baiting-encouraged by threatened newspaper and broadcast industries. Many lessons, parallels, and forgotten \\ antecedents for current American media policy can be drawn from the postwar 1940s. Thus, it is instructive to \\ explore how these earlier debates were framed, particularly in response to what might be referred to as "market \\ failure." Given the worsening journalism crisis and other persistent media policy challenges, this analysis of \\ market failure holds much contemporary relevance.
}

Postwar America saw the brief ascendance of a social democratic approach to media. In response to a journalism crisis with some similarities to the one that the United States and many other countries are facing today, progressive policymakers sought to lessen profit pressures on key parts of the news media. They argued that crucial public services should not be left entirely to market-driven forces, and attempted to establish safeguards to protect and sustain news media. An examination of the conflicting narratives within postwar policy debates suggests this approach was rejected largely because of a concerted backlash — often in the form of red-baitingencouraged by the newspaper and broadcast industries. The path the United States chose instead was based largely on a top-down corporate consensus rather than — as some Americans might assume today — a citizen uprising against governmental overreach.

Many of the conditions that gave rise to the contemporary journalism crisis can be traced back to policy debates in the 1930s (McChesney, 1993) and postwar 1940s (Pickard, 2010a). The 1940s in particular held many parallels to and lessons for current media-related challenges. Thus, it is instructive to explore how these earlier debates were framed, and what ideological narratives different constituencies relied on to reach specific policy positions. The following analysis draws from archival materials to shed light on the formation of the corporate libertarian paradigm that continues to orient U.S. media policy today. By focusing on the discursive tactics deployed by commercial broadcasters in the postwar era to defeat the regulatory threat of a muscular public interest mandate, we can better understand contemporary policy discourses that continue to mask the effects of systemic market failure.

The main objective in this article, therefore, is to understand the normative foundations of competing policy narratives that have important antecedents in the postwar 1940s. To tease out these underlying assumptions - beliefs that are often primarily ideological — I first explore the concept of market failure within the American media system, especially as it relates to the contemporary journalism crisis. Second, I show how narratives based on what I refer to as "corporate libertarian" ideology help manage and mask this systemic failure. Third, I focus on narratives within postwar media policy debates that highlight the conflicting logics of the corporate libertarian ideology compared to a more social democratic approach. Finally, I apply these theoretical formulations to current media policy debates, particularly those relating to the future of journalism.

\section{Journalism crisis $=$ market failure}

Market fundamentalism, or what I term "corporate libertarianism," remains the dominant paradigm in U.S. media policymaking. The logic of corporate libertarianism, as I explain in more detail below, assumes that the market is the most efficient and therefore the most socially desirable means for allocating important resources. However, assessing the current U.S. journalism crisis - as well as other social problems like the persistent digital divide - arguably challenges corporate libertarianism on its own terms. By closely scrutinizing the assumption that the American media system is the product of a "free market," or that it maximizes efficiency, we can bring into focus how a structural problem like the journalism crisis qualifies as a case of "market failure." Market 
failure, a concept drawn from mainstream neoclassical economic thought and explicated by various economists (see, e.g., Bator, 1958; Stiglitz, 1989; Medema, 2007), typically refers to a predicament where the market is unable to efficiently allocate resources, especially public goods. Often this occurs when private enterprise will not invest in critical social services because it cannot extract the profits that would justify necessary expenditures. Market failure has been cited as a justification for state intervention in the provision of public education and other social services and goods not supported by market transactions.

Evidence of market failure in the U.S. media system continues to accumulate, especially after long-term disinvestment in news production. The recent demise of the New Orleans Times-Picayune - which reduced staff by nearly a third and delivery to thrice-weekly in a city where $36 \%$ of residents lack internet connection - serves as a stark example of market failure and its negative impact on local communities. Whether as a description of the market's inability to support journalism or its deficiencies in providing universal access to affordable and reliable internet services, the phrase "market failure" arguably deserves central prominence in American media policy discourse. Yet a discussion of market failure, particularly how it figures in the journalism crisis, has been noticeably missing. This absence has been largely evident even in critical scholars' research - a consequence, perhaps, of the concept's neoclassical origins. But to advance the case for public policy intervention, especially within American policymaking circles where market fundamentalism still reigns, recognizing and correcting market failure is an essential task.

Related to this project is the recognition that our informational infrastructure is something more than a simple commodity. In recent years, a number of scholars have argued that the information produced by journalism should be treated as a public good (Hamilton, 2006; Pickard, Stearns \& Aaron, 2009; McChesney \& Nichols, 2010; Starr, 2011). Public goods are nonrivalrous and nonexcludable (Samuelson, 1954), and therefore difficult to monetize and to protect from "free riders." Journalism is a public good both in an economic senseespecially in its digital form - and in a socially desirable sense. It is not merely a commodity bought and sold like shoes or cars; rather, it is an essential public service with social benefits that transcend its revenue stream. In its ideal form, journalism creates tremendous positive externalities - that is, it produces benefits from the initial market transaction that do not necessarily go to either the buyer or seller - by serving as an adversarial watchdog over the powerful, covering crucial social issues, and providing a forum for diverse voices and viewpoints. As a core component of civil society, journalism functions as a vital infrastructure for democratic practice.

However, journalism - like many public goods - has never been fully supported by simple market transactions; it has always been subsidized. For over 125 years, this subsidy primarily has taken the form of advertising revenues. But that revenue model is becoming increasingly unsustainable as audiences and advertisers migrate to the Internet, where ads sell for a mere fraction of what advertisers pay for paper based products. As an approach to supporting journalism, this model appears to be irreparably broken, and no other commercial models, such as pay wall subscriptions, come close to replacing it. The inadequacy of commercial support brings us to the next step in this formulation: Recognizing that the market's systematic underproduction of the public good that is journalism qualifies as a clear case of market failure.

Mark Cooper (2011), one of the few analysts who have seriously considered market failure in the context of the journalism crisis, presents what he describes as a "traditional framework . . more familiar to policy makers" that encourages a "new direction of policy that is necessary to ensure a robust journalistic sector" (p. 321). Addressing such market failure with public subsidies arguably is not actually a "new direction" for American media policy — as the implementation of a public broadcast system at least suggests - but this policy framework has largely receded from contemporary discourse. Cooper provides some analytical tools with which to recuperate this understanding. He describes the five kinds of market Failure - societal failures, structural flaws, endemic problems, transaction costs, behavioral problems - and their implications for journalism. Cooper notes that McChesney and Nichols (2010) have amply demonstrated how the first two kinds of market failure clearly afflict journalism: societal failures in the form of insufficient support for public goods and positive externalities, as well as structural flaws in the form of monopolistic concentration and profit maximization, abuse of market power, and the resulting degradation in the quality of journalism. Adding empirical data to reinforce McChesney and Nichols' analysis, Cooper extends the critique to also argue that the other three forms of market failure affect journalism as well: The journalism crisis features endemic problems (conflicts of interest and perverse incentives), transaction costs (the high costs of physical distribution), and behavioral problems (the misperception of the value of civic discourse). 
The key point here, however, is that when market failure is detected, the historical and logical response has been to address it via public policy intervention. These actions have ranged from antitrust measures to public subsidies to more content oriented policies like the Fairness Doctrine, which mandated that broadcasters cover controversial issues important to local communities from opposing views in a balanced manner. Failure to act in the face of market failure, we could argue, amounts to "policy failure," especially from a public interest perspective. How a society responds to market failure — in this case, specifically to a media-related crisis — often depends on how the policy problem is framed within a particular narrative.

\section{The role of narrative in media policy}

Narratives play an important role in orienting media policy. They articulate democratic objectives, worthy beneficiaries, and threats to freedom. They identify the most efficient means to desired ends. They also tend to be reiterated through policy discourse as a shorthand explanatory device, particularly in media coverage meant for public consumption (Verhulst \& Price, 2008). Within media policy discourse, the thrust of these narratives can dictate whether and to what degree government intervenes in media markets via public policy. Once such narratives become broadly accepted, they often go unchallenged. Status quo assumptions thereby become commonsensical; questioning them increasingly falls beyond the parameters of acceptable discourse. Narratives, in other words, keep ideologies intact. While previous work has attempted to make sense of cultural narratives within the historiography of media policy (Vos, 2010), little research has focused on the role of narrative within media policy discourse.

Kunzler (2012) moves in this direction by elevating the role of "ideas" to a unit of analysis, arguing that the "force-of-ideas" approach to explaining media policy brings into focus normative underpinnings and policy paradigms. Kunzler's theorization helps explain by what process an issue becomes viewed as a policy problem, how normative goals are defined, and how the means to attain these objectives are decided. If we understand narratives as constructed of strategically interrelated ideas, Kunzler's formulation is very useful. However, my analysis of power relationships somewhat diverges from his framework in that I conceive ideas within media policy discourse as partly determined by Kunzler's two alternative approaches to explaining policy; namely, through the prism of political interests and institutional structures.

Seen through a lens of Gramscian theories of power (1971), narratives are disproportionately dictated by dominant interests in society - elite groups and organizations like politicians, media corporations, educational institutions, religious bodies, and so forth - but they also can be disrupted quite suddenly by social forces from below. Social movements, watchdog groups, and various activist and advocacy associations sometimes are capable of disrupting dominant discourses through strategic interventions. Still, while it is overly reductive to assume that policy outcomes always serve powerful interests, and unintended and ironic outcomes are not rare (Horwitz, 1989), policy narratives often help solidify relationships in favor of dominant incumbent players. Yet despite the power of incumbency, institutional inertia, and the pull of path dependency, maintaining hegemonic control over media policy requires a tremendous amount of maintenance and is always a messy, incomplete process. By normalizing and naturalizing power structures, narratives help provide the "glue" that binds these arrangements. For example, the narrative that constructs radio spectrum as private property (Coase, 1959) privileges individual rights, including those enjoyed by commercial broadcasters, over public rights. On the other hand, a counternarrative that the airwaves belong to the people supports the alternative policy regime that radio broadcasting is inherently a public medium.

Dominant narratives that succeed in orienting press coverage and other discursive constructions help restore paradigms, persuade publics, and contain challenges. Many of these functions of narrative are evident in postwar U.S. policy debates that saw the rise and fall of a social democratic vision of media. The outcomes of these policy battles between media reformers and powerful industry players had a tremendous impact on the way the American media system developed over the ensuing decades. Looking at how the conflicting policy orientations were constructed discursively, the following sections bring into focus what was at stake and how these positions were defined. Toward the end of the article I address contemporary implications, particularly around the subjects of current media policy paradigms and recommendations for recovering a social democratic reform agenda. Central to this study is the investigation of the underlying ideologies, narratives, normative assumptions and, finally, the politics that drove the development of the American media system.

\section{Methods and data collection}


To approach this project I am utilizing historical methods, including in-depth archival research of activist literature, memos, letters, and personal papers connected to individuals and groups that participated in 1940s broadcast policy debates, as well as close iterative readings of the trade press, mainstream news stories, and official industry and regulatory reports. Papers from the Federal Communications Commission (FCC, the main media regulatory body in the United States) provided a major source of policy documents for my analysis. When possible, I also analyzed public speeches made by leading spokespersons from industry, government, and activist groups. Finally, I gave close attention to the personal papers of FCC Commissioner Clifford Durr, whose range of contacts serve as a lens through which to glimpse the inner workings of a postwar media reform movement.

Beyond tracking down digital and analog copies of postwar news literature, my data gathering took place primarily at several key collections, including the Clifford Durr papers at the Alabama state archives in Montgomery; the James Lawrence Fly papers at Columbia University; the Dallas Smythe papers at Simon Fraser University; and the FCC papers at the National Archives at College Park, MD. At nearly all of these collections, I gained permission to use a digital camera, and took over 3,000 photographs. In addition to letters from members of the public, these collections typically included backchannel communications between progressive media reformers, as well as exchanges on strategies and tactics designed to contest discourse that emanated from industry representatives.

In interpreting the meaning and significance of these materials, I used what can best be described as critical discourse analysis to interrogate underlying biases to understand how power operates through texts and ultimately how it is constructed and reproduced (Van Dijk, 1993). In so doing, I also took historical and contextual factors into consideration as I looked for recurring themes, contradictions, and tensions. Scholars are only now beginning to use discourse analysis to examine media policy (see, e.g., Lentz, 2011), so there are few blueprints from which to draw, although arguably the method has been used by previous media scholars by a different name (see, e.g., Streeter, 1983). As Howarth notes (2000), this type of analysis focuses on language but also the conditions under which discourses are created and contested. In the 1940s, competing discourses about the role of radio in a democratic society - and the legitimacy of government to oversee that role-were on full display.

\section{Competing postwar logics}

At stake in the postwar 1940s were a number of core principles by which ownership and control of the U.S. media system would be governed. Many foundational policy decisions were made during a contentious period in the 1930s, when a commercial media system prevailed over nonprofit alternatives. Broadcasting, policymakers decided, would be primarily privately owned and supported by advertising revenue (McChesney, 1993), and print media institutions were able to fend off regulatory challenges from the Franklin D. Roosevelt administration (Pickard, forthcoming) and labor challenges from the Newspaper Guild (Scott, 2009). However, remaining undefined well into the 1940s were the public interest obligations that media companies, particularly broadcasters, owed society in return for the many privileges conferred upon them. Ultimately the United States moved away from a more muscular regulatory regime, but this was not an inevitable outcome. How this happened can be better understood by examining the underlying logics of two discrete policy visions that came into conflict in the 1940s: social democracy and corporate libertarianism. There are, of course, many shades of political thought between these positions, but for understanding the general trajectory of the U.S. media system over the past 70 years, it is instructive to tease apart these conflicting logics and the policy narratives that advance them.

\section{Social democracy}

The term "social democracy," like the term "liberal" in many nations, refers to both a political party and a political ideology (tenets of which are often shared by political parties other than Social Democrats). In this article, I refer to social democracy with the latter meaning in mind, particularly the underlying normative foundations and theories connected to its ideological project. As Thomas Meyer (2007) in The Theory of Social Democracy notes:

There are two normative premises that unite all versions of social democracy. First, "libertarian particularism," grounded in the primacy of relative liberty, is rejected in favor of a universal conception of liberty that ranks negative and positive liberty on par. Second, the identification of freedom and property 
is jettisoned in favor of a universal conception of liberty that balances the liberties of all parties against a property relationship as if they were equivalent. (p. 16)

In other words, social democracy elevates a positive liberty in which universal and collective rights-like those pertaining to publics and audiences and communities - are at least as important as the individual freedoms most cherished within libertarianism.

Social democracy has been more established as an ideological project and political position in advanced democracies outside of the United States, especially Western and Northern European countries. This ideology sees a legitimate role for an activist state that allocates resources in an egalitarian fashion, and endeavors to nurture a strong civil society by promoting public investments in institutions like museums, libraries, and schools. Skeptical of unregulated capitalism, social democracy sees value in a mixed economy and assumes that crucial services should be seen as public goods that warrant subsidizing and not left entirely dependent on the mercy of the market. With ideals ranging from strong labor unions to universal health care, this logic seeks to strengthen the foundations for a strong public sector through investments in critical infrastructures, including pubic media and education. A social democratic perspective assesses the value of a media system by how it benefits society as a whole, rather than the criteria of individual freedoms, private property rights, and profit for a relative few.

Postwar America was closer to following a social democratic trajectory in media policy than is generally acknowledged. A nascent media reform movement consisting of educators, labor unions, civil rights activists, and progressive intellectuals (Pickard, 2012), advocated for a number of progressive policy interventions and experimental models, ranging from nonprofit ventures to strong public interest mandates for commercial news organizations. Media policy debates rose to the fore, as reformers called into question the reigning laissez-faire relationship between U.S. media, the public, and the state. Progressive policy initiatives included the Supreme Court's 1945 antitrust ruling against the Associated Press (Blanchard, 1987), which called for government protection of "diverse and antagonistic voices" in the media; the 1946 Federal Communication Commission's (FCC) Blue Book, which outlined broadcasters' public service responsibilities; the 1947 Hutchins Commission on Freedom of the Press, which established democratic benchmarks for journalism, and finally the 1949 Fairness Doctrine, which defined broadcasters' basic public interest obligations (Pickard, 2008).

All of these policy initiatives were driven by an expansive view of the First Amendment. Drawing from Berlin's (1969) articulation of positive and negative liberties, it is noteworthy how these safeguards protected the audience's positive right to information as much as - if not more than-broadcasters' and publishers' negative rights that protected their speech and property from government intrusion. Furthermore, all of these initiatives provided for a proactive role for government to guarantee such positive liberties. The Hutchins Commission, particularly in their unpublished transcripts, grappled with these competing views of the First Amendment, noting that the entire notion of freedom of the press was rendered farcical unless everyone had access to media (Pickard, 2010b). Some Hutchins Commission participants also noted that the postwar era had witnessed the primary locus of threats against First Amendment freedoms shift from governmental tyranny to the private power of media corporations. Similar debates around the 1946 FCC Blue Book offer clear articulations of conflicting policy visions: media reformers pushed for community-controlled radio and close governmental oversight, while commercial broadcasters pushed for libertarian freedoms and self-regulation (Pickard, 2011a). As these two discrete visions came into conflict, their competing policies were cast into stark contrast. How these debates played out, and how their resolution would be inscribed in media policy, brings into focus the ideology that social democratic initiatives challenged.

\section{Corporate libertarianism}

"Corporate libertarianism" can be seen as social democracy's mirror opposite. While also discussing this logic in its American context, Korten (1995) employed the term to describe contemporary global neoliberal instruments like the World Trade Organization and the International Monetary Fund. Corporate libertarianism extends neoliberal logic (Harvey, 2005; Pickard, 2007) to suggest an apotheosis of market fundamentalism, combining the exaltation of absolute individual liberty with an attempt to discredit much that is public goodrelated. Further, this framework emphasizes that corporations should be increasingly empowered and emboldened to act as political agents, thereby undermining even weak public interest safeguards and redistributive mechanisms in U.S. society (Pickard, 2011b). The steady march of this libertarian logic has 
ushered in an unprecedented elevation of corporate power, often justified by invocations of individual liberty. Recently exemplifying this logic has been the Tea Party movement and conservative efforts to cut public sector employees' salaries, benefits, and labor freedoms in many states across the country. Largely ignoring widening inequities, corporate libertarians believe that allocating tax revenues to support social services is illegitimate, even if the wealthy are being taxed at historically low rates.

Corporate libertarianism took form in the early 20th century and crystallized during the postwar period after a long pro-industry campaign (Fones-Wolf, 1995), aided by anticommunist hysteria that helped defeat alternatives. It emerged in part from processes that other scholars have termed "corporate liberalism" (Weinstein, 1968; Streeter, 1996), a set of discourses that attempted to harmonize the contradictions between individual liberties and the industry imperatives of capital accumulation and private property. The logic of corporate libertarianism differs from what has been referred to as "corporatism," which sees a kind of powersharing arrangement between government regulators, labor unions, and business interests (McLaughlin \& Pickard, 2005). Corporate liberalism and corporatism allow for relatively minor conflicts and reforms - even if the core fundamental structure, often defined by oligopolistic markets, is kept intact and largely beyond the constraints of government regulation. Corporate libertarianism largely jettisons this arrangement, allowing a disproportionate amount of power to redound to corporate interests.

In the 1940s, this logic was illustrated by media companies' focus on defeating all forms of public interest regulation, often justified with rhetoric that equated corporate power and basic individual freedoms. While the differences between social democracy and corporate libertarianism strike at core assumptions about what kind of society we wish to inhabit, with regards to media, these ideologies help dictate what interests a communications systems should serve, whose stories are told, who has access to media and according to what terms. Exploring how these debates played out around media policy in the immediate postwar years brings a number of normative assumptions into view.

\section{The postwar argument}

In postwar media policy debates, broadcasters' antiregulation arguments rested on three themes. First, they argued that public interest regulations like those outlined in the FCC's Blue Book were an attempt to censor free speech, and thus an infringement of their First Amendment rights. A second standard line of reasoning was that educational and nonprofit broadcasting set-asides were unnecessary since the commercial system already provided these public services. This polemic was meant to head off structural interventions that de-privatized a portion of radio spectrum for public use. A third and final argument rested on the assumption that any kind of regulation of radio smacked of socialism, was antibusiness, and was therefore inherently nefarious and unAmerican. By assuming that radio had been invented and driven purely by private enterprise, they argued that any deviation from the "free market" - a mischaracterization, because it overlooked the fact that their monopoly rights to broadcast spectrum were antithetical to free market relationships - was a betrayal of radio's first principles.

The National Association of Broadcasters' (NAB) president demonstrated this last perspective when he informed a group of Kiwanians: "American radio today is the product of business!" Anticipating FCC chairman Mark Fowler's 1981 statement that television was nothing more than "a toaster with pictures," the NAB president insisted radio should be treated as a commodity, because "It is just as much the kind of product as the vacuum cleaner, the washing machine, the automobile and the airplane." Pegging 1935 as the time when "radio and its advertisers really began to get together and progress began," he asserted, "Many a station operator who might have had a personal preference for poetry and the opera learned some sound lessons in selling and merchandising under tutelage of America's good, hard-headed businessmen, and it was the best thing that could have happened to him" (quoted in Wecter, 1946). Elsewhere, calling recent regulatory attempts a "travesty," he was quoted as summing up the broadcasters' position: "We contend it is none of the Commission's business whether radio is commercial, too commercial, quasi-commercial or pseudo-commercial" (Broadcasting, 1947).

The most common trope in broadcasters' rhetoric was the notion of "Free Radio." In addition to appearing in Broadcasting magazine, variations of this theme appeared in postwar editorials and books. For example, NBC president Niles Trammell's congressional testimony was published as a pamphlet titled "Radio Must Remain Free," in which he urged the Senators in attendance to give radio a "new freedom from fear, the fear of the blight of government control" (Trammell, 1943, p. 6). Likewise, the NAB issued a thick book titled Broadcasting and the Bill of Rights based on statements made during another set of congressional hearings, 
particularly antiregulation arguments proposed by NAB president Justin Miller (National Association of Broadcasters, 1947). Libertarians did not control the definition of "free radio," however; like all such normative claims, its precise meaning was contested. Progressives attempted to place their own stamp on its construction in venues like The Journal of the National Education Association, which framed free radio as a positive liberty, defining it as "the widest possible range of information, entertainment, and ideas" (1944). And, ironically, the phrase would become something of a rallying cry for radio reform activists in subsequent decades. In the 1940s, however, corporate libertarians captured the term along with many normative frameworks for regulating media. The Republican presidential candidate Governor Thomas Dewey demonstrated its centrality in conservative ideology by declaring in 1944: "I believe that the FCC should have no right of censorship, that it should not control the content of radio programs. It should stay in the field of regulating technical facilities. And when the FCC starts to control program content, free radio goes out the window" (quoted in Wecter, 1946).

For their part, newspaper publishers, particularly those eager to acquire radio stations, kept the libertarian "Free Radio" motif in circulation. The Chicago Tribune publisher Colonel McCormick-who also had an interest in the Mutual radio network - argued that the FCC's regulatory power to review license renewals should be discontinued so that "wave lengths will become property and be protected in the courts like any other property" (Wecter, 1946). The "Free Radio" frame was also prominent in editorials published in Hearst-owned newspapers, exemplified by a piece titled "The American Radio Must Be Free."

[The U.S. constitution] should be amended to give the American radio the same recognition it gives the American press, and to assure it the same FREEDOM . . . . There is already a great deal of legislation respecting control of radio . . . but none of it has served to keep the radio FREE. The inherent weakness of such legislation . . . is that it depends for interpretation and enforcement upon bureaucratic agencies . . . which distort the law and assume and usurp powers under it in defiance of the authority of Congress and in contempt of the vital rights of the American people (Boston Daily Record, 1946).

Accusing the FCC of censorship and of parroting the Democratic party, the editorial quoted the Republican National Committee chair, Congressman Carroll Reece, as saying that radio "has fallen under the rule of seven bureaucrats setting themselves up as judges of what seventy million American radio listeners should be allowed to listen to." According to the article, this was an action "typical of the bureaucratic state where the private citizen is pushed around with arrogant contempt and allowed to listen only to those things which document the dogma of his masters"' (Boston Daily Record, 1946).

Print and broadcast media representatives responded by joining forces against the threat of government intervention. NAB president Justin Miller issued a call to arms mobilizing everyone connected to commercial media industries to fight a common enemy, the "strong government boys" who were to be found among the usual suspects: "sophomoric professors, selfish special interests, religious fanatics, power-crazed bureaucrats, and irascible legislators." These sinister conspirators had made common cause "to emasculate the media of free communication." While commercial media's "enemies chortle with glee," Miller warned, the government's machinations toward radio "can be done to the press, newspapers, magazines, books, and all varied forms of printed publications" (Miller, 1947, 1949, quoted in Stamm, 2011, p. 148). Elsewhere, he called for a "program of militant resistance to further encroachments of Government . . . upon radio's freedom"' (Broadcasting, 1946). According to an FCC release, he "branded talk about 'the people owning the air' as a 'lot of hooey and nonsense", (Federal Communications Commission, 1946).

Equating deregulated radio with the notion of freedom was more than just convenient sloganeering. Staking out "freedom" in American political discourse is the ultimate prize in rhetorical warfare. For broadcasters to frame their arguments in terms of "Free Radio" allowed them to lay claim to "American freedom" and all that is associated with such an esteemed position. Once they commanded that mountaintop, any counterargument could be dismissed as un-American. Indeed, although the notion of freedom is inherently unstable and contestable - meaning different things to different people at different times (Foner, 1998) anything not in line with freedom in American political discourse is a priori alien, cast outside the bounds of acceptable practice. Such discursive wrangling suggests that the struggle centered on the role of the state as much as media. It also suggests that the struggle was for much more than just control of radio or media in general; it was a struggle for political economic power, one that extended across many sectors of society and struck at the core of American corporate privilege. 
Much of this rhetoric originated with political and industry elites, but occasionally it also registered at the grassroots. In the many letters of complaint to the FCC about broadcasters' commercial excesses and the need for more regulation was a smattering of libertarian sentiments. For example, after reading about proposed radio regulations in the New York Times, one concerned citizen wrote to FCC Chairman Charles Denny that he should be "classed as a meddler and if not an actual Socialist, then something closely akin to it." Arguing that Congress gave the FCC the power to censor radio programs, he wrote "Perhaps the radio programs and the advertising plugs are moronic, but if that is what the people of the country want, why punish the radio stations and networks? Just remember that you were not selected to public office. You are there by sufferance" (McClelland, 1946). After hearing the progressive FCC Commissioner Clifford Durr debate policy on the radio, another listener wrote: "It is appropriate that I find time on Independence Day to tell you how contemptible your [position] was. Would that there were a freedom bath into which men of your alien mind could be immersed to come out clean and American"' (Luehr, 1946).

One listener saw the FCC's regulatory position resting on five presuppositions: "the law setting up the FCC was wise and good"; "the interpretation of the law by the FCC is wise and good and necessary"; "the public is not wise and 'Papa' [or] a bureau knows best"; " "the public is not vocal, hence [it] must have a voice [expressed by] that of a bureau"; and "private enterprise cannot be trusted." The listener concluded: "This attitude, low and bitter to free American citizens, stirs me to an indignation and sadness I cannot express." He asked, "How do you know the public needs uplifting by radio? How do you know what percentage of time should be devoted to this or that, or at what time of day certain types of programs should be put on?'" Suggesting that initiatives like the Blue Book was a waste of taxpayers' money, the listener concluded: "This attitude is paternalism, it is not trust in the "common man"" (McGinnis, 1946).

Commissioner Durr did his best to counter these arguments through opinion pieces in the media, public speeches, and constant promotion of the FCC's Blue Book, as grassroots groups rallied support for a more aggressive regulatory approach to radio. On the basis of the archival materials that I consulted, the vast majority of published opinions and public letters to the FCC were in favor of more regulation. This observation has been supported by some previous historical work, especially Fones-Wolf (2006). Brinson (2004, p. 130) notes that the great majority of letters to the FCC during the debates around what would later be known as the Fairness Doctrine were decidedly against deregulation; instead, they advocated for maintaining the strict Mayflower Rule, which forbade broadcasters' political editorializing.

Indeed, distrust toward commercial control of media was pronounced in the 1940s, particularly among

social movement groups, educators, religious organizations, and intellectuals (Pickard, 2012). One representative letter to Clifford Durr that exemplified support for more regulation of commercial radio began, "Three cheers and a slap on the back for a man after my own heart." Thanking Durr for reserving FM channels for ex-servicemen, the listener felt "quite certain" that he spoke "for many millions of my equally annoyed but less articulate fellow citizens." "Although one man against Proctor and Gamble is pretty poor odds," the listener acknowledged, "make it a good fight for a higher intellectual level of radio broadcasting, and we're with you one hundred percent" (Bingel, 1946). Another radio listener expressed skepticism about liberating radio from advertisers: "Here we have a three-hundred million dollar industry with its high pressure lobbyists in every form in constant descent upon members of Congress as well as your commission on one side, and the public like myself on the other side." Given these circumstances, the listener wondered "Just what can we do to halt [commercial control of radio], which should have belonged to the people?" (Nelson, 1946). Ultimately, it would prove to be a moot question, as corporate libertarianism crystallized to become the dominant policy paradigm, allowing commercial interests to consolidate their control over the still-new medium of radio and much of the American media system.

\section{Recovering a social democratic media policy program}

Even a casual glance will suggest that arguments against state intervention are as operative today as they were in the 1940s. Indeed, while these views were not treated as axiomatic in the 1940s, today they seem unassailable in mainstream policy discourse. As an article of faith, the notion that government should never intervene in media markets often requires no explanation. This view reigns despite incontrovertible evidence of market failure, ranging from a plummeting global ranking of American Internet (in terms of penetration, speed, and costs) to the ongoing collapse of commercial journalism. A social democratic orientation holds that it is the state's duty to shield vital infrastructures and social services - including news media - from unmitigated market 
logic. But historical developments in the United States have kept media policy on a different path. Bolstered by the regulatory state's retreat and corporate power's ascendance, this trajectory has been sustained by the capture of key institutions like regulatory agencies and courts, as well as decades-long public relations campaigns, AstroTurf groups, and corporate-funded think tanks. Taken together, this confluence has erased and obscured from popular discourse a more nuanced understanding of the social contract between corporations, government, and various publics.

Corporate libertarianism's increasing political clout in recent decades has had a profound impact on U.S. society. This is particularly true in the wake of the 2010 Supreme Court decision in Citizens United v. FEC, which stands to remake the political landscape along corporate libertarian lines by unleashing nearly unlimited funding from outside groups into political campaigns. This ascendance imperils core pillars of civil societygroups and institutions that might contest market fundamentalism - ranging from labor unions to libraries to community colleges. Drawing from the renowned economist John Kenneth Galbraith's (1952) notion that lessening the influence of concentrated power requires civil society institutions to serve as a "countervailing power," we should view journalistic institutions as an important component of this complex. But as long as news media are seen as business commodities shielded from regulation by negative liberties usually reserved for individuals, little recourse exists to create a viable public media system. If the history of postwar radio offers us any insights into the current journalism crisis, it reminds us that allowing major news media to be governed almost entirely by unregulated market forces can set a hazardous trajectory.

However, a change in course is possible. Media's systemic vulnerabilities become most clear during times of crisis when endemic tensions give way to overt market failure. These moments often witness brief openings within elite policy discourse for considering radical structural alternatives. Thus the current journalism crisis serves as a rare opportunity for strategic government intervention to lessen profit pressures on news media that could help actualize a more robust and democratic system. Such reform, however, first requires a critical reframing of the journalism debate. The first step in this reframing process is to debunk the standard libertarian case against progressive media regulation. Central to this project is Ed Baker's (2007) observation that two arguments have long been used to discredit government attempts to cultivate a vibrant media system: first, that the government has no legitimate role in markets, and second, that the First Amendment forbids government intervention in media markets specifically. Both of these arguments were deployed successfully in postwar policy debates, a time when many normative assumptions about the role of media in a democratic society crystallized. Corporate elites assumed a libertarian relationship between media and the audience, one that owed society little beyond entertainment. Even as the notion of social responsibility gained acceptance among media owners, it was largely defined by self-regulation and a First Amendment constrained by negative liberties.

These ideological assumptions continue to permeate U.S. policy discourse. This is true even of relatively liberal (in the U.S. political sense; not the economic sense) initiatives like the Federal Communications Commission's 2011 report on the future of media, which offered a highly critical assessment of American news media, but - perhaps fearful of its own logical conclusions - saw only a minor role for public policy in addressing the journalism crisis (Waldman, 2011a). Shortly after the report came out, its author suggested to a group of public advocates that a more definitive governmental role was inappropriate because the government should not be in a position to choose winners and because the First Amendment forbade it (Waldman, 2011b). Such arguments not only prove Ed Baker's point — and demonstrate the degree to which corporate libertarian logic has been internalized even by American liberal policymakers - but are demonstrably false. The government is always involved in markets, though often benefitting corporate interests.

American history shows that media oligopolies have not always been sanctioned; a long record exists of public policies aimed at curbing market excesses in communication systems. Furthermore, a proscription on government intervention in media stands on a highly dubious reading of First Amendment freedoms. If we are to take seriously important legal precedents, government intervention can be seen as mandated to ensure that a vibrant press system is structurally sound and protected. Indeed, there is a rich history of the U.S. government weighing in to ensure media systems serve public needs, as the historian Richard John's (1995) work on the U.S. Postal Service amply demonstrates. In recent decades, elite policy discourse seemingly has been hermetically sealed off from such ideas, but the current moment of crisis has created a potential opening to recover these lost understandings and to challenge oft-repeated mythologies about the illegitimacy of media policy interventions (Pickard, 2011c). 


\section{Conclusion}

In the postwar era, social democratic media policy initiatives sought to address market failure. However, during the mid-to-late 1940s these attempted reforms were overwhelmed by a corporate libertarian logic, which continues to define the parameters of much American media policy discourse. Refuting this logic is the first step toward recovering a social democratic policy orientation that is better suited to address worsening media problems, particularly the contemporary journalism crisis. Today, even modest policy changes could lessen the effects of market failure and bolster news organizations. While addressing market failure in the digital realm (Meinrath, Losey, \& Pickard, 2011) could hold many indirect benefits for news media, a number of policy reforms aimed specifically at journalistic institutions are also viable. For example, tweaking tax laws could eliminate barriers to innovative nonprofit ventures and help struggling news outlets transition to new business models. And significantly strengthening American public media would be a strong first step toward funding an alternative media infrastructure insulated from those commercial pressures that directly contributed to today's journalism crisis. Right now, the United States is an outlier among advanced democracies for how little it funds its public broadcasting (Benson \& Powers, 2011).

The case for press subsidies stems from the social democratic assumption that a healthy communication system should not be overly dependent on market relationships. Therefore, according to this logic, commercial pressures, and profit motives should be minimized or entirely removed from large sectors of the news media, especially in the wake of what Mark Cooper (2011) calls "pervasive market failure." This reframing of the journalism crisis allows for both commercial and noncommercial models-a structurally diverse media system - that restores balance between profit-making and democratic imperatives and is better able to withstand market fluctuations. Also important is the hope that once a society acknowledges it is facing market failure, the need for government action via public policy becomes more acceptable.

To be sure, economic structures do not determine all aspects of a media system. Even a well-funded independent press will be affected by different journalistic cultures and audience interests. Moreover, in contemporary times it is increasingly difficult to articulate a notion of "the public" or "public interest." Such categories must always be grounded in a conception of diverse and multiple publics, and they must always negotiate the charge, leveled in the 1940s as now, of being paternalistic. Nonetheless, by enabling alternative media structures, especially nonprofit models, enlightened policies can encourage new journalistic cultures and dynamic relationships with diverse audiences. Elements of a mixed model — a hallmark of social democracycould be drawn from various public media institutions employed by other democracies. Already-existing community institutions in the United States like cooperative news organizations and nonprofit media could serve as building blocks for an alternative media system. However, these models will require some form of public subsidy based on a social democratic understanding that the market alone will not support the communication requirements of a democratic society. Given American media's tendency toward excessive commercialism and oligopoly control, it stands as a poignant reminder of what may happen when a key informational infrastructure is left largely to market governance.

Ideological reactions notwithstanding, it is government that can best alleviate various forms of market failure, particularly the inability to support public services ranging from education and health care to public media and the arts. As evidence of market failure accumulates, public policy interventions remain the only viable approach to a media system no longer supported by market mechanisms. Calling for such state support, however, is still treated as a dangerous argument beyond the bounds of acceptable political discourse. Yet given that government, in its ideal form, is a collective response to social problems, the main purpose for creating such a centralized authority is arguably to provide for public goods.

The late historian Tony Judt (2010) noted that a normative foundation for a more social democratic society begins with determining whether a policy is good or just instead of profitable or efficient. With the discursive shift toward the latter, Judt became resigned to see contemporary times as forever disproving that there exists an inexorable march toward a more progressive future. He suggested that many current struggles in Western democracies must focus on merely retaining the victories of previous reformers, preventing policies from worsening, and harboring a vision of a better society for some distant and more opportune moment. While Judt's observations may be largely correct at present, we need not take such a bleak view. Policy discourse is not set in stone; it is fluid and subject to interventions from below - and it can change suddenly and dramatically. In recent times, the Occupy Wall Street movement catalyzed just such a profound shift in policy narrative, pivoting the national conversation from a fixation on debt, austerity, and deregulation to instead focus on social 
democratic concerns about jobs and inequality. Despite many rise-and-falls and false starts for progressive media reform, history provides grounds for guarded optimism. In media policy debates during the 1940s, one can glimpse the emergence of a largely forgotten social democratic tradition. Although it often received public support, this impulse was countered by a largely elite-driven rhetoric that equated "freedom" with deregulation. Different outcomes may have added additional contours to the American media system, including more educational and independent news outlets. The current journalism crisis may create another rare opportunity to jettison flawed commercial news models in favor of democratic alternatives. Toward those ends, we can look to international models employed in other democracies as well as those that were attempted or considered within American historical traditions. These models were designed to compensate for the market's failure to support the communication needs of a democratic society.

In the United States, tensions between social and economic imperatives in media policies remain unresolved. In the 1940s, policymakers tried but failed to remove media from direct market control and to build safeguards to protect a more public interest-oriented system. Had these reformers not been defeated by industry groups, and had the United States then followed a social democratic course, perhaps American media would not again face many of the same challenges today. But despite such path dependencies, these past ideological struggles remind us that profound paradigm shifts are not inconceivable. They merely require the political will.

\section{References}

Associated Press v. United States. (1945). 326 U.S. 1, 20.

Baker, C. E. (2007). Media concentration and democracy: Why ownership matters. New York, NY: Cambridge University Press.

Bator, F. M. (1958). The anatomy of market failure. Quarterly Journal of Economics, 72(3), 351-379.

Benson, R., \& Powers, M. (2011). Public media and political independence: Lessons for the future of journalism from around the world. Washington, DC: Free Press.

Berlin, I. (1969). Two concepts of liberty. In I. Berlin (Ed.), Four essays on liberty. London, England: Oxford University Press.

Bingel, A. (1946, July 22). [Letter to Clifford Durr]. Clifford J. Durr Papers (Box 30, Folder 7). Alabama Department of Archives and History, Montgomery, AL.

Blanchard, M. (1987). The associated press antitrust suit: A philosophical clash over ownership of first amendment rights. Business History Review, 61, 43-85.

Brinson, S. (2004). The red scare, politics, and the FCC, 1941-1960.WestPort, CT: Praeger. Broadcasting (1947, September 22). 14.

Citizens United v. Federal Election Commission. (2010). 558 U.S. 08-205.

Coase, R. (1959). The Federal Communications Commission. Journal of Law and Economics, 2, 1-40.

Cooper, M. (2011). The future of journalism: Addressing pervasive market failure with public policy. In R. McChesney, \& V. Pickard (Eds.), Will the last reporter please turn out the lights: The collapse of journalism and what can be done to fix it (pp. 320-339). New York, NY: The New Press.

Federal Communications Commission. (1946, May 3). Release 92873.

Foner, E. (1998). The story of American freedom: 1776-2005. New York, NY: W.W. Norton.

Fones-Wolf, E. (1995). Selling free enterprise: The business assault on labor and liberalism, 1945-1960. Urbana, IL: University of Illinois Press.

Fones-Wolf, E. (2006). Waves of opposition: Labor, business, and the struggle for democratic radio. Urbana, IL: University of Illinois Press.

Galbraith, J. K. (1952). American capitalism: The concept of countervailing power. Boston, MA: Houghton Mifflin.

Gramsci, A. (1971). Selections from the prison notebooks. New York, NY: International.

Hamilton, J. (2006). All the news that's fit to sell. Princeton, NJ: Princeton University Press.

Harvey, D. (2005). A brief history of neoliberalism. New York, NY: Oxford University Press.

Horwitz, R. (1989). The irony of regulatory reform: The deregulation of American telecommunications. New York, NY: Oxford University Press.

Howarth, D. (2000). Discourse. Buckingham, England: Open University Press.

John, R. (1995). Spreading the news: The American postal system from Franklin to Morse. Cambridge, England: Harvard University Press.

Judt, T. (2010). Ill fares the land. New York, NY: Penguin Press.

Korten, D. (1995). When corporations rule the world. West Hartford, CT: Kumarian Press. 
Kunzler, M. (2012). 'It's the idea, stupid!' How ideas challenge broadcasting liberalization. In N. Just, \& M. Puppis (Eds.), Trends in communication policy research: New theories, methods and subjects. ECREA Book Series (Vol. 7, pp. 55-74). Bristol, England: Intellect.

Lentz, R. (2011). Regulation as linguistic engineering. In R. Mansell, \& M. Raboy (Eds.), The handbook of global media and communications policy (pp. 432-448). Malden, MA: Blackwell.

Luehr, E. (1946, July 4). [Letter to Clifford Durr]. Clifford J. Durr Papers (Box 30, Folder 7). Alabama Department of Archives and History, Montgomery, AL.

McChesney, R. (1993). Telecommunications, mass media \& democracy: The battle for the control of U.S. broadcasting, 1928-1935. New York, NY: Oxford University Press.

McChesney, R., \& Nichols, J. (2010). The death and life of American journalism: The media revolution that will begin the world again. New York, NY: Nation Books.

McClelland, L. (1946, March 8). [Letter to Charles Denny]. Clifford J. Durr Papers (Box 30, Folder 5). Alabama Department of Archives and History, Montgomery, AL.

McGinnis, J. C. (1946, July 21). [Letter to Clifford Durr]. Clifford J. Durr Papers (Box 30, Folder 7). Alabama Department of Archives and History, Montgomery, AL.

McLaughlin, L., \& Pickard, V. (2005). What is bottom up about global Internet overnance? Global Media and Communication, 1(3), 359-375.

Medema, S. G. (2007). The hesitant hand: Mill, sidgwick, and the evolution of the theory of market failure. History of Political Economy, 39(3), 331-358.

Meinrath, S., Losey, J., \& Pickard, V. (2011). Digital feudalism: Enclosures and erasures from digital rights management to the digital divide. CommLaw Conspectus: Journal of Communications Law and Policy, 19, 423-479.

Miller, J. (1947, June 26). Purpose of meeting. Opening remarks to the all-media conference of freedom of expression, Washington D.C.

Miller, J. (1949). "Attacks on Freedom of Communication." Address to American Society of Newspaper Editors Convention, Statler Hotel,Washington D.C.

Miller calls for halt to inroads. (1946, January 14). Broadcasting, 30, $14,17$.

National Association of Broadcasters. (1947). Broadcasting and the Bill of Rights. Statements presented by representatives of the broadcasting industry during hearings in the White Bill (s. 1333).

Nelson, F. (1946, August 12). [Letter to Clifford Durr]. Clifford J. Durr Papers (Box 30, Folder 7). Alabama Department of Archives and History, Montgomery, AL.

Pickard, V. (2007). Neoliberal visions and revisions in global communications policy from NWICO toWSIS. Journal of Communication Inquiry, 31(2), 118-139.

Pickard, V. (2008). Media democracy deferred: The postwar settlement for U.S. communications, 1945-1949. (unpublished doctoral dissertation). University of Illinois, Urbana, IL.

Pickard, V. (2010a). Reopening the postwar settlement for U.S. media: The origins and implications of the social contract between media, the state, and the polity. Communication, Culture \& Critique, 3(2), 170-189.

Pickard, V. (2010b). Whether the giants should be slain or persuaded to be good: Revisiting the Hutchins Commission and the role of media in a democratic society. Critical Studies in Media Communication, 27(4), 391-411.

Pickard, V. (2011a). The battle over the FCC Blue Book: Determining the role of broadcast media in a democratic society, 1945-1948. Media, Culture \& Society, 33(2), 171-191.

Pickard, V. (2011b). First they came for everyone: The assault on civil society is an injury to all. International Journal of Communication, 5, 1820-1826.

Pickard, V. (2011c). Can government support the press? Historicizing and internationalizing a policy approach to the journalism crisis. Communication Review, 14(2), 73-95.

Pickard, V. (2012). The air belongs to the people: The rise and fall of a postwar radio reform movement, Critical Studies in Media Communication. DOI: 10.1080/15295036.2012.705436

Pickard, V. (Forthcoming). Laying low the shibboleth of a free press: Regulatory threats against the American newspaper industry, 1938-1947. Journalism Studies.

Pickard, V., Stearns, J., \& Aaron, C. (2009). Saving the news: Toward a national journalism strategy. In Changing media: Public interest policies for the digital age (pp. 187-240). Washington, DC: Free Press.

Samuelson, P. (1954). The pure theory of public expenditure. Review of Economics and Statistics, 36, 387-389.

Scott, B. (2009). Labor's new deal for journalism: The newspaper guild in the 1930s (unpublished doctoral dissertation). University of Illinois, Urbana.

Stamm, M. (2011). Sound business: Newspapers, radio, and the politics of new media. Philadelphia, PA: University of Pennsylvania Press.

Starr, P. (2011). Goodbye to the age of newspapers (hello to a new era of corruption). In R. McChesney, \& V. Pickard (Eds.), Will the last reporter please turn out the lights: The collapse of journalism and what can be done to fix it (pp. 1837). New York, NY: The New Press.

Stiglitz, J. (1989). Markets, market failures, and development. American Economic Review, 79(2), 197-203. 
Streeter, T. (1983). Policy discourse and broadcast practice: the FCC, the US broadcast networks and the discourse of the marketplace. Media Culture \& Society, 5, 247-262.

Streeter, T. (1996). Selling the air: A critique of the policy of commercial broadcasting in the United States. Chicago, IL: University of Chicago Press.

The American Radio Must Be Free. (1946, May 24). Boston Daily Record.

The Journal of the National Education Association. (1944). Volume 33.

Trammell, N. (1943, December 7-8). 'Radio must remain free.' Statement given before the Senate Interstate Commerce Committee.

Van Dijk, T. (1993). Principles of critical discourse analysis. Discourse Society, 4(2), 249-283.

Verhulst, S., \& Price, M. (2008). Comparative media law research and its impact on policy. International Journal of Communication, 2, 406-420.

Vos, T. P. (2010). A cultural explanation for early broadcast policy: Professionalism, voluntarism, and U.S. broadcast networks. Journal of Broadcasting \& Electronic Media, 54(2), 179-193.

Waldman, S. (2011a). The information needs of communities: the changing media landscape in a broadband age. Washington, DC: Federal Communications Commission. Available at www.fcc.gov/infoneedsreport.

Waldman, S. (2011b, June 14). Future of media report public interest briefing with Steve Waldman. New America Foundation, Washington, D.C.

Wecter, D. (1946, May 18). The public domain of the air. The Saturday Review of Literature IXIX, 20, 5-6, 36-38.

Weinstein, J. (1968). The corporate ideal in the liberal state, 1900-1918. Boston, MA: Beacon Press. 